\title{
COMMERCIALLY AVAILABLE ANTI-S-100 PROTEIN SERUM STAINS M. LEPRAE IN LEPROSY TISSUES BY IMMUNOHISTOCHEMICAL PROCEDURES.
}

Demonstration of bacilli and consequently of their antigenic products is easily fcasible in multibacillary (LL, BL, BB) forms of leprosy. However, the presence of a non specific chronic inllammatory infiltrate, as seen in indeterminate leprosy, or the persistence of a granuloma in the paucibaccilary (BT, TT) forms of leprosy in the absence of demostrable bacilli, may indicate that free antigenic products are initiating the apparently non-specific inflammation and/or perpetuating the granuloma (9).

Immunohistochemistry proved to be useful to demonstrate infectious organisms and/or their antigens in tissues. Antigenic analysis indicates that there are common antigenic sites among mycobacterial species. On this basis rabbit antiBCG serum has been widely used as the primary antibody to demonstrate both the bacilli and their antigens in leprosy tissues $(5,6)$. Recently monoclonal antibodics against $M$. leprae have becn produced which recognise specific antigens on cell surfaces of leprosy lesions (8).

A phenolic glycolipid with a structure related to mycoside A of Mycobacterium kansasii was found in M. Ieprae preparation and had its structure clucidated by HUNTER \& BRENNAN (3) and HUNTER, FUJIWARA \& BRENNAN (4). A highly specific trisaccharide for serodiagnosis of leprosy was synthesized and proved to be highly sensitive in ELISA (1). This synthetic trisaccharide (ST) is antigenic and anti-scrum against it was raised in rabbits by a standard procedure, using incomplete Frcund's adjuvant, and was used as primary antibody in an avidin-biotin peroxidase immunohistochemical reaction by us. In multibacillary leprosy, bacilli and/or their antigens were heavily stained in essentially similar manner by anti-BCG and anti-ST sera. In paucibacillary leprosy isolated macrophages in the granuloma were stained by both anti-sera, probably indicating antigenic products which might be relevant in the perpetuation of the granulomatous inflammation.
S-100 is an acidic calcium binding protcin so-named because of its solubility in $100 \%$ ammonium sulphate solution at neutral $\mathrm{pH}$; it is distributed in the brain of a wide variety of specics and is regarded as species non-specific (7). The finding of S-100 antigen in non-nervous tissues and, particularly in antigen-presenting cells of the skin in normal conditions, suggests that S-100 should no longer be considered strictly as a nervous system specific protein. In paucibacillary leprosy S-100 antigen detection was used as a marker to culaneous nerve branches, sinee dermal nerves impairment by inflammatory reaction permits the differential diagnosis between paucibacillary leprosy and other skin granulomatosis (2).

A positive staining of Mycobacterium leprate and/or its antigens with commercially available (DAKO, Denmark) polyclonal anti S-100 rabbit serum was detected by us in multibacillary leprosy. Esscntially similar antigenic sites were demostrated by S-100, anti BCG and anti ST sera. Lepromin absorbed anti S-100 serum failed to stain bacilli but maintened its staining properties as far as antigen presenting cells and dermal nervous branches were concerned. Therefore, the use of non-specifically absorbed commercial anti S100 protein polyclonal scrum in paucibacillary leprosy stains structures known to be usually stained by this anti-serum logether with bacillary antigens. The staining propertics of $\mathbf{M}$. Ieprae by commercially available (DAKO) polyclonal anti $\mathrm{S}-100$ protein scrum is really an artefact. This anti-scrum is raiscd in rabbits using complete Freund's adjuvant, which contain mycobactcria. Consequently different antibodics are present in the anti-serum, some recognizing M. leprae and others recognizing $\mathrm{S}-100$ protein.

Therefore, care should be taken when using in immunohistochemical procedures commercially available anti-scrum in infectious discases, chiefly in countries where tuberculosis and leprosy are endemic. 
SIQUEIRA, S.A.C.; WAKAMATSU, A.; ALVES, V.A.F. \& DE BRITO, T. - Commercially available anti-S-100 protein serum stains M. leprae in Icprosy tissues by immunohistochemical procedures. Rev. Inst. Med. trop. S. Paulo, 32( ): - , 1990.

\section{REFERENCES}

1. CHO, S.N.; FUJIWARA, T.; IIUNTER, S.W.; REA, T.H.; GELBER, R.H. \& BRENNAN, P.J. - Use of an artificial antigen containing the 3,6-di-0-methyl-D-glucopyranosyl epitope for the serodiagnosis of leprosy. J. infect. Dis., 150:311-322, 1984.

2. FLEURY, R. \& BACCHI, C.E. - S-100 protein and immunoperoxidase technique as an aid in the histopathologic diagnosis of leprosy. Int. J. Leprosy, 55:338-344, 1987

3. HUNTER, S.W. \& BRENNAN, P. - A novel phenolic glycolipid from Mycobacterium leprae possibly involved in immunogenicity and pathogenicity. J. Bact., 147:728-735, 1981.

4. HUNTER, S.W.; FUJIWARA, T. \& BRENNAN, P.J.Structure and antigenicity of the major specific glycolipid antigen of Mycobacterium leprae. J. biol. Chem., 257:15072-15078, 1982.

5. MSHANA, R.N.; BELEHU, A.; STONER, G.L.; HARBOE, M. \& HAREGEWOIN, A. - Demonstration of mycobacterial antigens in leprosy tissucs. Int. J. Leprosy, 50:1-10, 1982.

6. MSHANA, R.N.; HUMBER, D.P.; BELEHU, A. \& HARBOE, M. - Immunohistological studies of skin biopsies from patients with lepromatous leprosy. J. clin. Immunol., 3:22-29, 1983.

7. NAKAJIMA, T.; WATANABE, S.; SATO, Y.; KAMEYA, T.; HIROTA, T. \& SHIMOSATO, Y. - An immunoperoxidase study of $\mathrm{S}-100$ protein distribution in normal and ncoplastic tissues. Amer. J. Surg. Path., 6:716-727, 1982.

8. NARAYANAN, R.B.; RAMU, G.; SINHA, S.; SENZUPTA, U.; MALAVIYA, G.N. \& DESIKAN, K.V. - Demostration of Mycobacterium leprae specific antigens in leprosy lesions using monoclonal antibodies. Indian J. Leprosy, 57:258-264, 1985.

9. RIDLEY, D.S. - I Iistological classification and the immunological spectrum of leprosy. Bull Wld. Hlth Org., 51:451-465, 1974

"Instituto Adolfo Lutz", S. Paulo Health Service and Institute of Tropical Medicine, USP.

S.A.C. Siqueira

A. Wakamatsu

V.A.F. Alves

T. De Brito

Recebido para publicação cm 22/2/1990. 